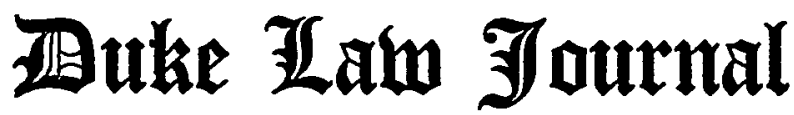

VoLUME 1966

SUMMER

NUMBER 3

\section{MOVIE CENSORSHIP: A SWISS COMPARISON}

\section{Francis WILliam O'Brien *}

Obscenity and censorship are perhaps the most unsettled areas of constitutional law in this country today. To many, the deep divisions and divergent attitudes of the Justices of the Supreme Court constitute an intolerable state of affairs for a functioning system of jurisprudence. This article will not present a panacea for these problems. But in an area where disagreement abounds, examination of the approach of another legal system can lead to clearer thinking, reorientation of analysis, and a better over-view of the entire area. Since many of the problems which have plagued the courts in this country have likewise been raised in Swiss censorship litigation, the reader should find Swiss solutions enlightening.

$\mathbf{T}$ HE MOST recent decisions by the Supreme Court of the United States on censorship ${ }^{1}$ have only served to multiply the confusion surrounding this important area of constitutional law. The existence and strength of widely divergent views among not only the high court's Justices but also the various forces in our society appear to be almost irreconcilable. In this type of situation, it is interesting and instructive to examine the approach taken to the censorship problem in other countries whose legal systems are similar to our own. Such a country is Switzerland, and this

- A.B. 1941, M.A. 1942, Gonzaga University; M.A. 1952, Boston College; Ph.D. 1956, Georgetown University; Certificat d'Études Françaises 1961, Universite dé Poitiers. Visiting Professor of Constitutional Law, l'Université de Lausanne, Switzerland. Author, Prayer and Religion in Swiss Schools, 42 N.C.L. REv. 791 (1964); The Engel Case from a Swiss Perspective, 6l Micr. L. REv. 1069 (1963); Church and State in Switzerland: A Comparative Study, 49 VA. L. Rev. 904 (1963); Baker v. Carr Abroad: The Swiss Federal Tribunal and Cantonal Elections, 72 YALE L.J. 46 (1962).

1 Mishkin v. New York, 383 U.S. 502 (1966); Ginzburg v. United States, 383 U.S. 463 (1966); A Book Named "John Cleland's Memoirs of a Woman of Pleasure" v. Attorney Gen., 383 U.S. 413 (1966). 
article will compare the law of Swiss censorship-limited to censorship of movies-to that existing in this country.

\section{I}

\section{General Framework of Swiss Law}

Switzerland is a federal republic embracing 22 states-called cantons-containing five and one-half million people. It is a country roughly comparable in size to the states of Vermont and New Hampshire combined.

The Swiss people, like our own, have always possessed an independent spirit, love of liberty, and devotion to democratic institutions. Lord Bryce wrote that Switzerland "has pushed democratic doctrines farther, and worked them out more consistently, than any other European State."2 Recently a knowledgeable expert said that "Switzerland is often thought of as the most democratic of modern state systems." 3

The Swiss have delegated to the central authorities only those powers deemed absolutely necessary to handle problems no longer amenable to local solution. As might be expected, these powers are somewhat more ample than those granted to the national government in a vast country like our own. Nonetheless, the Confederation appears to be highly respectful of the rights of the cantons to legislate without interference on matters truly local in nature. Thus a respected Swiss scholar has said:

The principle of our federal state is to reserve to its members, the cantons, sovereignty in those domains where power. ought to be held as close as possible to one's person and conscience. These sacredly reserved domains are: that of public education, that of church-state relations, that of the minority tongues. ${ }^{4}$

The "principle" referred to by the professor just quoted finds expression in article 3 of the Swiss constitution: "The cantons are sovereign insofar as their sovereignty is not limited by the federal constitution, and as such they exercise all the rights which are not delegated to the federal power." The tenth amendment to the American Constitution is almost identical: "The powers not dele-

\footnotetext{
? Bryce, Modern Democracies 327 (1921).

3 Codping, The federal Government of Switzerrand 55 (1961).

- Address by Professor Gonzague de Reynold, in La Liberté (Fribourg); Aug. "1; 1962, p. 1, col. 2.
} 
gated to the United States by the Constitution, nor prohibited by it to the States, are reserved to the States respectively, or to the people." Article 27ter, added to the Swiss constitution in 1958, specifically allocates the power to legislate on movies and their production between the local and federal governments. It authorizes the federal government to legislate for the encouragement of the film industry, but further provides that in all other respects "cinema legislation and its application are within the competence of the cantons."

Even where legislative power is granted to the cantons, however, the latter often act only with the close cooperation of the central government. And in every case, should local authorities actually infringe personal liberties, a supreme court of the central government-the Tribunal Federal-stands as a court of last appeal:

The constitutional provisions which restrict governmental action vis-à-vis the individual are strikingly similar to those in the United States. Article 4 provides that "all Swiss are equal before the law," and, as will be indicated below, is interpreted by Swiss courts analogously to the equal protection clause of our fourteenth amendment. $^{5}$ Other constitutional provisions safeguard freedom of conscience and belief, ${ }^{6}$ the press, ${ }^{7}$ association, ${ }^{8}$ and opinion. ${ }^{9}$

II

\section{The Swiss Censorship Approach}

Before discussing individual points of comparison between Swiss and American law, it will be advantageous to set out the general approach to movie censorship developed by the Tribunal Federal. This approach in itself is of comparative significance. In addition, it provides a framework within which the reader can

\footnotetext{
- See also Swiss CoNst. 1874, art. 60: "Every canton is bound to accord to citizens of the other confederated states the same treatment as to its own citizens in regard to legislation and all that concerns judicial proceedings."

- Swiss Const. 1874, arts. 49, 27. Swiss authorities are in the process of drafting a revised constitution which will eliminate restrictions found in arts. 50, 51, and 52all vestiges of former times.

7 Swiss Const. 1874, art. 55.

${ }^{8}$ Swiss Const. 1874, art. 56. Additional guarantees punctuate the constitution at several points. See, e.g., Swiss CoNsr. arts. 57, 58, 106, 112, 113.

' No provision of the federal constitution expressly guarantees freedom of opinion. Most of the cantonal constitutions, however, have such a provision. E.g., ZuRIck CoNsr. art. 8. Additionally, article 55, protecting freedom of the press, is often interpreted to include freedom of opinion, but it does not apply to the cinema. See part IV $\mathbf{D}$ of this article infra.
} 
judge how Swiss solutions to particular censorship problems might work in the United States.

\section{A. "White Slavery"}

Section 25 of an ordinance of the Canton of Zurich provides: "The showing of films immoral, corrupting or in another manner improper is forbidden; likewise the advertisement of cinema presentations by title, poster, leaflets or insertions of this nature."10 On April 8, 1953, the Department of Police of Zurich forbade the showing of a film entitled "Traite des Blanches" (White Slavery) because of "the criminal character of the film; its manner of presenting the world of pimps and white slavery; its coarseness and widespread brutality-all of which is 'corrupting and improper' according to section $25 \ldots . .11$

The Gamma-Film Distribution Company appealed to the Conseil d'Etat, the seven-member Executive of the Canton of Zurich, in June of 1953.12 The appeal was rejected, whereupon Gamma took its case to the Tribunal Federal.

The Tribunal correctly discerned the basis of the Council's action. "[T] he Conseil d'Etat admits that the film is not immoral, but judges it to be corrupting and repulsive." 13 This standard was not, the Tribunal felt, overly vague:

The ordinance of Zurich does not say what is necessary for something to be corrupting or improper. But the meaning of these words is clear; a film is corrupting and improper if it is capable of

${ }^{10}$ Quoted in Gamma-Film Distribution S. A. contre Conseil d'Etat, Tribunal Fédéral, March 3, 1954, at 1 (Swit.). (This is an unreported decision. Only a certain percentage of decisions of the Tribunal Federal are published and printed in the official reports.)

The word "improper" is a translation of the French word choquant. It can also mean "offensive" or "unpleasant."

It is interesting to note that there are no national laws proscribing immoral films, this being an area reserved for cantonal legislation. But there are national laws which forbid obscene printed material and illustrations.

11 Ibid.

12 See $i d$. at 3 .

${ }^{13} I d$. at 8 (all translations are the author's).

The Tribunal does not give in any of the cases a definition of "immorality." However, in 1927 it said of "obscenity": "A publication is obscene in the sense of the federal law of September 30,1925, when; objectively, by its subject and the fashion of treatment, it is likely to shock sexual decency, when its end is essentially to arouse the sexual passions, when it intends no scientific or artistic purposes, and when because of the method of propaganda and because of the people reached it threatens to exert a corrupting action on morals." A. K. contre Tribune de Police, Tribunal Fédéral, July 7, 1927, 53 (I.) Arrêts du Tribunal Fédéral 234 (Swit.). 
having an unfavorable influence on morals and of offending the sensibilities of spectators and listeners. ${ }^{14}$

It is questionable, of course, whether this standard for censorship could pass constitutional muster in the United States. ${ }^{15}$ Nevertheless, the appellant did not directly attack the ordinance. Rather, "the appellant, comparing the film to a book, seems to plead . . . a violation ... of Article 3 of the Constitution of Zurich which guarantees liberty of opinion."16 The judges impatiently rejected this argument:

As the Tribunal Federal has declared on repeated occasions, a general police regulation of industry, decreed to safeguard public order ... cannot be attacked because it transgresses the guarantee of another constitutional liberty (liberty of conscience and belief, liberty of the press, liberty of association and of assembly). It is the same for liberty of opinion which is only an extension of liberty of the press and other means of expression. ${ }^{17}$

The rationale underlying this principle is quite clear: The constitution does indeed guarantee liberty of religion, for instance, but a person could not be allowed to pollute the air nor murder his children in the name of some religious conviction, no matter how sincere he might possibly be. Likewise, if civil authorities were to judge that a written work constituted a danger to the public welfare, the author should not be allowed to advance freedom of the press or freedom of opinion as a barrier against its legal prescription.

At first blush, this seems to be totally inconsistent with the situation in the United States. But it must be remembered that the Swiss are highly community conscious, revere tradition, and faithfully abide to democratic decisions. They are not libertarians in their view of first amendment freedoms and do not accept the thesis that the great guarantees give any person a license to subvert the

\footnotetext{
14 Gamma-Film Distribution S. A. contre Conseil d'Etat, Tribunal Fédéral, March 3, 1954, at 8 (Swit.).

${ }^{15}$ See, e.g., Holmby Prods., Inc. v. Vaughn, 350 U.S. 870, reversing mem. $177 \mathrm{Kan}$. 728, 282 P.2d 412 (1955) ("tend to debase or corrupt morals"); Superior Films, Inc. v. Department of Educ., 346 U.S. 587 (1954), reversing mem. 159 Ohio St. 315, 112 N.E.2d 311 (1953) ("immoral and harmful"); Commercial Pictures Corp. v. Regents of the Univ., 346 U.S. 587 (1954), reversing mem. 305 N.Y. 336, 113 N.E.2d 502 (1953) ("tend to corrupt morals"); Gelling v. Texas, 343 U.S. 960 (1952) ("prejudicial to the best interests of the people").

${ }^{10}$ Gamma-Film Distribution S. A. contre Conseil d'Etat, Tribunal Fédéral, March 3, 1954, at 8 (Swit.).

${ }^{17}$ Ibid.
} 
established order as determined by long tradition and community decision. In other words, the Swiss never forget that "the people," as well as the isolated individual, also have liberties, which ought not be sacrificed on the altar of devotion to the claims of every parvenu. To cite one example: In accordance with ageless tradition and local desires, religious instruction is given in every school. No child may be obligated to follow such instruction, but this freedom from religion would never be conceived of as a license for one person to restrict the liberty of others to opt for this kind of training. For the Swiss, it is not only a question of the liberty of the community pitted against the nonconformist; it is, rather, the liberty of the one versus that of a multitude of individuals expressing themselves in a collective fashion. The constitution enshrines both freedoms in article 49: religious conscience is guaranteed as well as parental rights in the education of children.

Hence it is easy to see, as will be further developed below, why the Swiss tolerate a higher degree of censorship by the cantons than is allowed to local communities in the United States. Nevertheless, the interest of the individual, as we shall see, is one factor affecting censorship decisions, and a basis for comparative analysis thus remains:

\section{B. Nudist Films}

Werner Kunz is a Swiss promoter of nudist films. In April 1960 the Conseil d'Etat of the Canton of Geneva reluctantly granted him a permit for a movie entitled "Nous irons à l'ile du Levant" (We Will Go to the Isle of Levant). ${ }^{18}$ The Isle is a well-known camp for nudists in France. The Council limited the showing to those over eighteen and remarked that it was reserving its judgment "in regard to all nature or nudist films which might be presented to it" in the future.

Three months later the Police Department banned two other movies of Kunz: "Vacances Naturistes" (Vacations for Naturists) and "Naturists dans la Neige" (Naturists in the Snow). The prohibition rested on article 41 of a Geneva regulation concerning places where public performances may be given. The pertinent, part forbids "performances contrary to morals and public order,

\footnotetext{
${ }^{18}$ See Kunz contre Conseil d'Etat, Tribunal Fédéral, Dec. 7, 1960, at 2 (Swit.).
} 
notably those which present bloody acts or those which are of a nature to suggest, to provoke or to glorify criminal or unlawful acts."18

In upholding this ban, the Council of Geneva-its collegiate executive-affirmed that the films in question served as propaganda for naturism, which "in the present state of public opinion ... is contrary to the views of the great majority of the population of the people of Geneva."20 Consequently, "it would not conform to public opinion to permit the showing of these films."21

The Tribunal Federal noted first ${ }^{22}$ the power of the cantons to regulate "trade and industry and taxation thereof," 23 and continued:

Thus it is solely a question of discovering if the regulation has been applied in the instant case in a manner conforming to the Constitution. The Tribunal Federal can review this question only. under the narrow angle of Article 4 of the Constitution [arbitrary and unequal treatment]. It ought to be all the more restrained inasmuch as in this matter it acknowledges the broad power of judgment [vesting] in cantonal authorities, and it does not intervene unless these authorities have manifestly abused their prerogatives. ${ }^{24}$

But after thus professing abnegation, the Tribunal went on to say:

The problem being thus circumscribed, the Tribunal Federal has not to offer its judgment about the doctrine of naturism itself and about the comportment of its adepts in places which are reserved for the cantons. Its sole duty is to investigate whether or not it is contrary to Article 4 of the Constitution to consider as

\footnotetext{
19 Ibid.

so Id. at 2-3.

פI Id. at 3.

22 Actually, Kunz' first argument was that the Council's action was arbitrary and thus infringed the equal protection clause of article 4 of the federal constitution because the Council had allegedly upheld the ban of the Police Department without citing the text of any law and without stating the precise legal provisions with which the films collided. Id. at 5-6. The Tribunal answered that if the law had required Geneva's Council of State to be more precise in citing chapter and article, then "perhaps" its omission to do so might constitute a violation of article 4. But there was no such obligation. Moreover, continued the Tribunal, it was clear beyond any doubt that the Council intended to uphold the prohibition as formulated by the Police Department, i.e., a ban grounded upon article 41 of Geneva's regulation of movie houses prohibiting performances "of a nature to suggest, to provoke or to glorify criminal or offensive acts." The Tribunal did, however, suggest that the Council would be better advised to explicate itself more precisely as to which part of article 41 was involved. Ibid.

${ }^{32}$ SwIss CoNST. 1874, art. 31.

${ }^{34}$ Kunz contre Conseil d'Etat, Tribunal Fédéral, Dec. 7, 1960, at 7-8 (Swit.).
} 
contrary to public order and morality cinematographic strips which permit the public at large to see naturists put their convictions into practice. ${ }^{25}$

This really seems to be an avowal of something less than absolute judicial self-denial, and thus emulates the usual approach of American courts to legislative judgments. Geneva's Council of State had already expressed its mind on the subject: naturism was contrary to current public opinion and to the views of the majority, and therefore films of propaganda for its cause should not be permitted. ${ }^{28}$ The Tribunal Federal confessed its lack of authority to challenge the first part of this judgment of the Council; certainly it had no duty to question public opinion and to put any judicial stamp of approval-even provisionary approval-on naturism. But it would assume the duty of investigating whether or not the second judgment of the Council collided with the equality clause of article 4 of the constitution. Its investigation and conclusions are expressed thus:

The film entitled "Vacances Naturistes" includes a part devoted to the Ile de Sylt and which, for the most part, presents the ordinary holidays of numberless tourists at the seashore, and briefly, at the end, the beach reserved for naturists. Three other portions show nature centers in England ... and in France .... . Insofar as nudists are concerned, the actors wear tights or are photographed in such a manner that their sex parts are not visible. They move about within a framework which is essentially that of nature (vast prairies, beaches, the sea) and with such their nudity is not out of harmony. Their postures are not questionable from a sexual standpoint. ${ }^{27}$

The Tribunal seems, indeed, to be giving its personal opinion on the harmlessness of the film "Vacances Naturistes," and thus to be laying down its own standard of what may be constitutionally banned. On the other hand, the Tribunal further stated:

It is true that the simple expectation of seeing in a film naked men and women can be a natural attraction for a certain type of spectator impelled by an unhealthy curiosity. From this point of view, Article 41 would perhaps permit authorities to intervene $\ldots . .{ }^{28}$

\footnotetext{
${ }^{25} \mathrm{Id}$. at 8 .

${ }^{20} \mathrm{Id}$. at 2-3.

${ }^{27} I d$. at 8.

${ }^{28}$ Ibid.
} 
Thus it is unclear whether the Tribunal would constitutionally overturn the judgment of Geneva's Council of State because of disagreement on the harmful effects of the movie. This uncertainty was not resolved in the case, because the Tribunal struck down the ban on other grounds, to be discussed later. ${ }^{29}$

The Tribunal next turned its attention to "Naturistes dans la Neige."

This film represents the frolicking of four young naked women in the snow. The impression gotten from it is different from that made by the other two films. Whereas, in them, there is a certain rapport between the nudity of the actors and the framework in which they find themselves, the gambolings of naked women in the snow awakens a feeling of something contrary to nature, and the scenery presented on the screen appears to serve only as a pretext to display to the spectator naked women in most sundry positions: In the other two films the varying landscapes are relatively unknown to the average spectator and offer to them alone a certain interest. The mountain scenes which "Naturistes dans la Neige" present are on the contrary so familiar to an inhabitant of this country that the only interest of the film strip rests in the naturist part of $i t^{30}$

This distinction drawn by the Tribunal between the two films may appear exceedingly ingenuous: the Swiss are so jaded by their own mountain scenery that they could only have eyes for the naked women, but English countryside is so alluring that they wouldn't see the nudes for the trees!

Thus it is difficult to determine whether the Tribunal was straining more to upset part of the decision of the Conseil d'Etat or more to uphold part of it, and what, if any, constitutional standards it may have been applying. In any case the Tribunal concluded thus:

The appellant is not able to complain of unequal treatment. The differences cited above are ... sufficiently accentuated so that the film "Naturistes dans la Neige" can reasonably be considered as apt to awaken, especially in young movie-goers, an unhealthy curiosity and, thus, to jeopardize morals and public order. Consequently a prohibition of its presentation is not manifestly unwarranted in virtue of Article 41 [of Geneva's ordinance on public performances]. ${ }^{31}$

\footnotetext{
${ }^{29}$ See text accompanying note 99 infra.

${ }^{30} \mathrm{Kunz}$ contre Conseil d'Etat, Tribunal Fédéral, Dec. 7, 1960, at 10 (Swit.).

sx Id. at 10-11.
} 
Whatever one may say about the meaningfulness of the distinctions made by the Tribunal between the two films, it is clear that the judges have indicated they are fully aware of the many various and delicate factors which must be taken into consideration before passing judgment on whether and to what extent movies impinge upon public morals. And from the following cases it will become clear beyond doubt that the high tribunal thinks the weighing of these facts is a duty best reserved to local authorities.

\section{G. Further Decisions}

In 1961, the Tribunal reviewed the film "Plein Soleil" (Bright Sun). ${ }^{32}$ The production had been prohibited in the canton of Neuchatel as being "contrary to morals, cynical, particularly suggestive in the manner of presenting the premeditation of crimes and their execution."3s The Department of Police issued its ban under a 1929 decree of the cantonal Conseil d'Etat forbidding "public performances contrary to morality or public order, especially those which are by their nature apt to suggest or provoke criminal and unlawful acts." 34

In upholding the action of the Neuchatel authorities, the Tribunal made several comments which merit recording here.

According to modern ideas, the police power is limited to the maintenance of public order; it has for its mission protecting against troubles which unlimited liberty would involve; in this respect it has its right to take measures appropriate to safeguard morality, tranquility, security and public well-being.

Thus the authority, in assisting parents and the school, must take into account, in authorizing the showing of films, the age of spectators; often the health of employers of the cinema branch will not be irrelevant; other measures will focus on the public in general. ${ }^{35}$

The Tribunal then spoke of the large discretionary power which must vest in local authorities.

In the first place, the maintenance of order and public morality belongs to the cantons; in charging themselves with it, they have also every latitude possible within the framework of the constitu-

\footnotetext{
${ }^{32}$ Sphinx-Film S. A. contre Conseil d'Etat, Tribunal Fédéral, Jan. 6, 1961, at 2 (Swit.).

${ }^{33}$ Ibid.

${ }^{34}$ See $i d$. at 2.

${ }^{35} I d$. at 5 .
} 
tions and the laws. In the second place, the demands of order and public morality vary freely according to circumstances and local opinions; federal law would not be able to trace uniform limits between that which is permissible and that which is not; it matters little, in this respect, what is the regulation laid down outside of a particular canton. The domain of the cinema, finally, presents such particularities that the showing of a film, more than other public performances, is subject to varied and contingent evaluations. ${ }^{36}$

In the same year, in Filmklub Lucerne contre Conseil d'Etat, ${ }^{37}$ the Tribunal upheld another ban, once again making a number of deferential gestures in the direction of local governmental authority. For example, the Tribunal said it would not go into a detailed analysis of the cantonal law in question, for

the Tribunal Federal is not commissioned to play the role of super authority for cinema censors, nor to take the steps necessary to maintain public order; this in the first place is the task incumbent upon the authorities of the cantons, which enjoy a broad measure of liberty of action and of judgment. In addition, the opinions as to what constitutes a menace for public order and in particular for morals, and views as to means for their protection, depend for the most part upon given local data and dominant political and religious ideas, [facts] which stand in opposition to the setting up of broad and uniform standards for the whole of Switzerland.38

\section{D. "The Nudist Story"}

"The Nudist Story" was a film banned in Geneva in 1963 under the same ordinance mentioned above. This prohibition was upheld by the Tribunal Federal in Regina-Film contre Conseil d'Etat. ${ }^{38}$

In justifying the ban placed upon the movie, Geneva's Council of State had declared that since its authorization of "Nous irons a l'ile du Levant," and since the public showing of "Vacances Naturistes"-by Tribunal decree-it had become evident that stricter control over movies was called for. More specifically, the Council was now "confirmed" in "the idea" that there was "a certain public, composed especially of young people" which was seeking "in nudist shows . . . sexual excitement undesirable from the point of view of

so Id. at 8 .

37 Tribunal Fédéral, July 12, 1961, 87 (I.) Arrêts du Tribunal Fédéral 117 (1962) (Swit.).

sa Id. at 119.

so Tribunal Fédéral, Sept. 25, 1963 (Swit.). 
public morality." 40 The Tribunal accepted this reasoning and rejected Regina's request that the movie's exhibition be allowed in Geneva.11

In reading the opinion of the Tribunal, one notices that it abounds with professions of restraint and deference to the judgment of local authorities. When regulating commerce in order to protect morality and public order, the cantons are not to go beyond what is strictly necessary, but "the Tribunal Federal will not review their decision in this regard except in a case of arbitrariness and manifest error." 42 . More explicitly, in its judgments of films, "the Tribunal Federal will uphold the opinion of cantonal authorities as long as it is not evidently false or arbitrary." 43

Appellant asserted that in authorizing the film "Nous irons à l'ile du Levant" in April 1960, the Council had shown it did not consider nudism as something contrary to the morals of the people of Geneva. ${ }^{44}$ But the judges accepted the Council's subsequent act of repentance and firm purpose of amendment:

The cantonal authority has explained itself: . . . in authorizing the film "We Will Go to the Isle of Levant," it did not recognize the unhealthy attraction which nature films exercise over youth. ... [T] $]$ his argument justifies a change in administrative practice. 45

Regina-Film also argued that there were nudist groups practicing their cult in Geneva, and by tolerating them, the Council of State had admitted that this practice is compatible with morality. ${ }^{48}$ Thus, appellant concluded, it was arbitrary to forbid all propaganda in favor of nudism. The Tribunal rejected this contention:

The cantonal authority does indeed speak of nudism as being a method of life contrary to our mores, and this scarcely accords with the activity which nudist groups seem to carry on in a legal fashion in the Canton of Geneva. Nonetheless, the film "The Nudist Story" has been banned not solely because it favors a move-

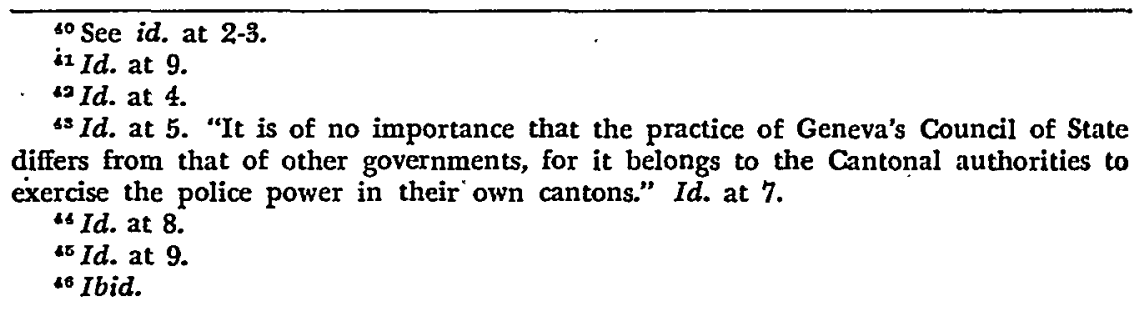


ment contrary to mores but rather and especially because in itself it is an offense to morals and public order. Now as this results from the preceding considerations, this argument is solidly grounded and is sufficient in itself to justify the decision which is attacked. Thus, the complaint of arbitrariness rings untrue. ${ }^{47}$

It is important to note, however, that the Tribunal did indulge in some review and independent determinations. This is shown by the manner in which it met appellant's charges that another film"Nights of Paris"-revealed seven methods of undressing, ${ }^{48}$ and that cabarets and night clubs presented displays similar to those in "The Nudist Story." 49 The Tribunal observed that "Nights of Paris" was authorized before the new policy of stricter control had been adopted, and significantly added that the strip-tease scenes were not its essential element, ${ }^{50}$ whereas in "The Nudist Story" the nudists played the principal role, ${ }^{51}$ and people appeared completely naked from beginning to end of the film..$^{52}$

As for the cabarets and night clubs, the Tribunal underscored the fact that "the dancing had only a limited clientele and the individual was for the most part warned in advance, while the cinema drew upon an extremely vast and unsuspecting general public."'53

There are solid grounds for distinguishing between a large cinema appealing to the public at large and the intimacy of a cabaret with its limited number of patrons. It is somewhat more difficult to accept the suggestion that many, if any, people fall into a nudist movie by accident or drop in casually under the false impression that they are about to see Mickey Mouse. ${ }^{54}$

Nonetheless, the Tribunal did apply its own judgment to the film. But it is inescapable that the tone of the whole opinion is one of deference to local authorities in matters of cinema censorship.

\footnotetext{
"I Ibid.

48 Id. at 8.

"OId. at 3 .

${ }^{\text {so }} \mathrm{Id}$. at 8.

${ }^{31}$ Ibid.

${ }^{82} 1 d$. at 6-7.

${ }^{83} \mathrm{Id}$. at 3.

su It would have been much more apposite to underscore the difference between taking no action against the cultists and positively authorizing a nudist film. The state has no obligation to legislate against every evil. Compare Williamson v. Lee Optical, Inc., 348 U.S. 483, 489 (1955). Indeed, political prudence frequently dictates tolerance of activities contrary to accepted moral standards of a community when carried on privately or in small groups and in such a manner as to cause no substantial harm to the common good.
} 


\section{E. "Girls of the Sun God"}

This same spirit of restraint motivated a decision by the Tribunal in May of 1963 in the case of Kunz contre Conseil d'Etat..$^{\mathrm{t5}}$ In upholding the Council's ban on "Les Filles du Dieu Soleil" (Girls of the Sun God), the court offered the following comments:

Public morality is essentially an element of order. In this domain, the responsibility in the first instance rests upon the cantonal authority which is, better than any other, in a position to judge local circumstances. ${ }^{56}$

The authorities in Geneva are satisfied with asserting that a certain public, made up especially of young people, go there [to nudist films] to find unhealthy thrills .... . There is no need to prove such an assertion. ${ }^{57}$

The appellants reproach . ... the Conseil d'Etat for having advanced its new argument without being convinced of it, solely to satisfy the demands laid down by the Tribunal Federal in its decree of December 7,1960 . This complaint is manifestly devoid of all justification; it is even temerious. ${ }^{58}$

As to the precise reason for banning "Girls of the Sun God," the Tribunal echoed the conclusion of the Council of State that this was "a film constituting clear propaganda for nudism which is contrary to our mores and offensive to a great majority of the population." 59

\section{F. A Summary}

This brief review of the relevant Swiss cases clearly indicates that the Tribunal Federal's approach is quite different from that of the prevailing opinions of the United States Supreme Court. First, of course, the Tribunal has not taken the definitional course which the Supreme Court has developed: that which is "obscene" is not within the ambit of the first amendment and therefore is not entitled to constitutional protection. Rather, the Tribunal assumes constitutional protection and goes on to "balance" much the way that the Supreme Court does in the ordinary first amendment case.

Secondly, it is obvious that movies are not considered "speech,"

${ }^{86}$ Tribunal Fédéral, May 1, 1969, 89 (I.) Arrêts du Tribunal Fédéral 166 (Swit.).

so $1 d$. at 169 .

${ }^{87}$ Ibid.

ss Ibid.

so Id. at 166. 
and hence do not merit preferred constitutional protection. ${ }^{60}$ Thus, when the "speech" in a movie comes in conflict with a valid regulation under the police power, the latter, if reasonable, will prevail. In addition, the scope of permissible police power regulation is somewhat broader than would be allowable in the United States.

Thirdly, the Tribunal Federal exercises great restraint in judging cantonal censorship. This is probably a result of its deep respect for Swiss federalism, consideration for community standards, appreciation of cantonal differences, and regard for the judgment of local authority. ${ }^{61}$ Even the factual determinations of these authorities on possible disturbing effects which might occur from the showing of a particular film are seldom questioned.

The Tribunal feels that any attempt to impose uniform laws throughout the Republic would represent sheer folly. ${ }^{62}$ The result is that twenty-five different jurisdictions ${ }^{63}$ are authorized to legislate for the cinema in a country of only five and one-half million people living in an area one-two-hundredths the size of the United States.

The Tribunal Federal has not, however, totally abdicated its position as a protector of individual rights. It stands ready to reverse cantonal decisions which constitute unequal treatment or which represent unreasonable and arbitrary action. ${ }^{64}$ This "reasonableness" test can be illustrated by rulings that the cantons might prohibit the showing, of movies on the Sundays of Advent, but not during prolonged periods of time-for example, all of Advent or

\footnotetext{
${ }^{\circ 0}$ Movies do not fall within the protection of any specific constitutional provision. See part IV D of this article infra.

${ }^{-}$For an illustration of how extensive this deference can be, see note 22 supra. See also Rey contre Ministre public, Tribunal Fédéral, Dec. 3, 1963, [1964] Journal des Tribunaux 149 (Swit.), where the Tribunal reproached but did not reverse the cantonal court for failing to specify which pictures in a magazine were obscene after admitting that some were not obscene.

"Compare the view of Mr. Justice Harlan, dissenting in A Book Named "John Cleland's Memoirs of a Woman of Pleasure" v. Attorney Gen., 383 U.S. 413, 458 (1966): "The varying conditions across the country, the range of views on the need and reasons for curbing obscenity, and the traditions of local self-government in matters of public welfare all favor a far more flexible attitude in defining the bounds for the States."

"There are only twenty-two cantons, but three of them have split into "half" cantons, each with its own parliament.

" Compare the view of Mr. Justice Harlan, dissenting in A Book Named "John Cleland's Memoirs of a Woman of Pleasure" v. Attorney Gen., 383 U.S. 413, 458 (1966): "From my standpoint, the Fourteenth Amendment requires of a State only that it apply criteria rationally related to the accepted notion of obscenity and that it reach results not wholly out of step with current American standards. . . The latitude which I believe the States deserve cautions against any federally imposed formula listing the exclusive ingredients of obscenity and fixing their proportions."
} 
Lent; ${ }^{85}$ the Tribunal has simply concluded that while the one regulation is reasonable, the other is patently an unreasonable restraint of the cinema industry.

The fact that the Tribunal does and will impose limitations on the breadth of censorship action taken by the cantons gives a comparative study great validity. While the general approach and attitude of the Tribunal contain significant differences from those of the Supreme Court, the differences fall more into the "where to draw the line" category than the "how to draw the line" category.

In relation to where the line should be drawn, several other factors should be borne in mind in making this comparative study. First, the danger of a criminal prosecution for obscene movies is quite small in Switzerland, and hence more arbitrariness will be tolerated. Secondly, the film industry in Switzerland is still largely undeveloped. Most of the films under consideration are produced outside of the country, and a proportionate part of the profits are thus not available to the Swiss economy. One can only speculate as to the extent of the effect these and other like factors have on censorship law-but surely the existence of an effect cannot be doubted.

With these considerations in mind, let us delve into a comparison of Swiss and American law.

\section{III}

\section{Comparative Problems}

Since it appears that the Tribunal Federal's control over movie censorship is not wholly unlike the function performed by the United States Supreme Court, but rather differs only in the degree and particulars in which that control is exercised, an excellent basis is afforded for comparative analysis of the manner by which various particularized censorship problems are solved. This section will concentrate on those problems which have been raised in both countries and which therefore lend themselves to direct comparison.

${ }^{\circ 5}$ Siegried contre Vaud, Tribunal Fédéral, Feb. 5, 1915, 41 (I.) Arrêts du Tribunal Fédéral 40 (Swit.); Morandini contre Luzern, Tribunal Fédéral, Sept. 15, 1989, 59 (I.) Arrêts du Tribunal Fédéral 107 (Swit.); Held contre Neuchatel, Tribunal Fédéral, Nov. I9, 1914, 40 (I.) Arrêts du Tribunal Fédéral 479 (Swit.); Note, 49 Schweizerisches Zentralblatt Für Staats-und Gemeindeverwaltung 908 (1948). Thus the Tribunal has ruled that it is an unreasonable restraint of trade to force cinemas to close for long periods or for several days a week even if the motive is a noble one, as, for example, "to prevent the useless spending of money or to restrain the desire for pleasure." 


\section{A. Prior Restraint}

Swiss thinking on prior restraint starts from the premise that wide latitude should be given local authorities to exercise the police power. This factor, combined with the Tribunal's somewhat relaxed attitude toward the importance of "speech," leads inevitably to the conclusion that prior restraint is an acceptable mode of censorship.

The [public] authority can protect public order, in the area of cinema representations, in diverse manners; thus it may set up a system of prior censorship or, in case of necessity, forbid a showing even after the beginning of a performance. ${ }^{66}$

The Supreme Court, on the other hand, has unanimously indicated in Freedman v. Maryland $d^{67}$ that prior restraint will be tolerated only if careful procedural safeguards are provided.

\section{B. Scope of Review}

One of the most perplexing and yet unresolved issues which has faced the Supreme Court is the scope of review which should be afforded in obscenity cases. ${ }^{88}$ While the position of the Tribunal Federal is somewhat clearer, it too is not free from ambiguity.

Chief Justice Warren, dissenting in Jacobellis $v$. Ohio, ${ }^{69}$ said:

I would commit the enforcement of [the constitutional obscenity standard] ... to the appropriate state and federal courts, and I would accept their judgments . . . limiting myself to a consideration only of whether there is sufficient evidence in the record .... [P]rotection of society's right to maintain its moral fiber and the effective administration of justice require that this Court not establish itself as an ultimate censor . . . . ${ }^{70}$

This statement is quite similar to the Tribunal's words in the Filmklub Lucerne case:

The Tribunal Federal is not commissioned to play the role of super authority for cinema censors, nor to take the steps necessary to maintain public order; this in the first place is the task incumbent

\footnotetext{
${ }^{\circ B}$ Sphinx-Film S. A. contre Conseil d'Etat, Tribunal Fédéral, Jan. 6, 1961, at 5 (Swit.). See note 121 infra.

o7 380 U.S. 51 (1965).

${ }^{8}$ See generally Comment, The Scope of Supreme Court Review in Obscenity Gases, 1965 DUKE L.J. 596.

๑8 378 US. 184 (1964).

${ }^{70} \mathrm{Id}$. at 202 (Warren, C.J., dissenting).
} 
upon the authorities of the cantons who in fulfilling it enjoy a broad measure of liberty of action and of judgment. ${ }^{71}$

It is probably safe to assume that this statement represents the view of the Tribunal, and that de novo review, at least to the extent that it would compel the judges to see the film itself, is not a requirement. This conclusion is muddied slightly, however, by the fact that in the "White Slavery" case, the Tribunal did watch excerpts of the film, and then indicated that it could not judge from excerpts alone whether the film taken as a whole was "improper and corrupting throughout."72 Does this mean that if the appellant had shown the Tribunal the entire film, it would have made a judgment on its propriety?

Whatever may be the answer to that question, the Tribunal has clearly held that the Councils, appellate bodies themselves, need not see the film in question en banc. A Council can delegate this chore to experts or rest its judgment on the opinion of those of its members deemed most competent in these matters. ${ }^{73}$

\section{Elements of the Obscenity Definition}

The Tribunal has not given a definition of "obscenity" in any of the movie censorship cases. It has defined the term in a slightly different context, however:

A publication is obscene . . . when, objectively, by its subject and the fashion of treatment, it is likely to shock sexual decency, when its end is essentially to arouse the sexual passions, when it intends no scientific or artistic purposes, and when because of the method of propaganda and because of the people reached it threatens to exert a corrupting action on morals. ${ }^{74}$

This definition is somewhat more extensive than the basic Roth definition.75 It seems to incorporate Roth's "patent offensiveness"

\footnotetext{
71 Filmklub Lucerne contre Conseil d'Etat, Tribunal Fédéral, July 12, 1961, 87 (I.) Arrêts du Tribunal Fédéral 117, 119 (1962) (Swit.).

${ }^{79}$ Gamma-Film Distribution S. A. contre Conseil d'Etat, Tribunal Federal, March 3, 1954, at 10-11 (Swit.). The Tribunal does at times ask to view a film in its entirety. See Sphinx-Film S. A. contre Conseil d'Etat, Tribunal Fédéral, Jan. 6, 1961, at 3 (Swit.), where the judges viewed two films to make a comparison.

${ }^{3} \mathrm{Id}$, at $4,6-7$.

${ }^{4}$ A. K. contre Tribune de Police, Tribunal Fédéral, July 7, 1927, 53 (I.) Arrêts du Tribunal Fédéral 234 (Swit.). While the Tribunal was here considering literaturc, the definition would seem to apply to movies as well.

${ }^{75}$ Roth v. United States, 354 U.S. 476, 489 (1957): "whether to the average person, applying contemporary community standards, the dominant theme of the material taken as a whole appeals to prurient interest."
} 
and "prurient interest" concepts, and goes on to include notions of "redeeming social value," ${ }^{\circ}$ the method of advertising, 77 and a weighing of the effect on the intended audience. ${ }^{78}$

\section{Taken as a Whole}

The Swiss Tribunal agrees with the Supreme Court that a movie must be judged as a whole, and that a decision on its propriety cannot be made on the basis of only a few excerpts. ${ }^{79}$ It is interesting to note, however, that this principle frequently seems to work against the Swiss film exhibitor. Thus, for example, where an appellant attempted to justify a film because it "carried a valuable message," and in which the criminal was eventually brought to justice, the Tribunal stated:

This rectification, accidental and hasty, as though outside the work, does not erase from the spectator's mind the narration, which he has just seen, of a perfect crime. Thus it is not unreasonable, on the part of the cantonal authorities, to reproach the banned work as being apt to lead to crime. Such a category of spectators can easily conclude that with a little more skill, the hero would have escaped justice; if he fails, it is due to bad luck, not because of the logical chain of events, according to a natural result. The Conseil d'Etat might legitimately admit that the moral justification brought in in the final sequence is not real, is superficial, pure form, and that it does not reverse the thought that the perfect crime is possible and that it pays off handsomely. ${ }^{80}$

Another film was prohibited even though it proposed "an end not immoral or inadmissible. It is sufficient that it presents repeated scenes which are of a nature to produce . . . injurious effects."81

\footnotetext{
"A majority of the Court does not agree that this is a part of the "obscenity" definition. See notes 108-10 infra and accompanying text.

${ }^{77}$ In Ginzburg v. United States, 383 U.S. 463 (1966), the Court held that the method of distribution and advertising is one factor bearing on whether the material is "obscene."

${ }^{73}$ See part III $\mathrm{F}$ of this article.

${ }^{79}$ See, e.g., Regina-Film S. A. contre Conseil d'Etat, Tribunal Fédéral, Sept. 25, 1963, at 8 (Swit.); Gamma-Film Distribution S. A. contre Conseil d'Etat, Tribunal Fédéral, March 3, 1954, at 10-11 (Swit.). In Rey contre Ministre public, Tribunal Fédéral, Dec. 3, 1963, [1964] Journal des Tribunaux I49 (Swit.), the Tribunal upheld a conviction for selling obscene magazines with this observation: "The characterizing of such publications as obscene ought to rest more on the impression d'ensemble which they awaken in the reader than on such or such detail."

${ }^{80}$ Sphinx-Film S. A. contre Conseil d'Etat, Tribunal Fédéral, Jan. 6, 1961, at 10 (Swit.). While this case did not involve obscenity, the principle would nevertheless be clearly applicable.

B1 Gamma-Film Distribution S. A. contre Conseil d'Etat, Tribunal Fédéral, March 3, I954, at 8 (Swit.).
} 
2. To the Average Person

Presumably the Tribunal also feels that it is the average member of the audience who must be considered in judging the propriety of a film. In a case involving obscene magazines, the Tribunal held that to apply an obscenity statute it was necessary to consider "not a particular individual, but the average observer in the milieu of a given civilization."82

\section{Patent Offensiveness}

The Swiss also seem to apply some sort of a "patent offensiveness" standard in judging movies. A film was banned, for example, because it was "capable of having an unfavorable influence on morals and of offending the sensibilities of spectators and listeners."83

\section{Redeeming Social Value}

The concept of "redeeming social value" has also been raised in Swiss litigation. The Tribunal recognizes that a film may "represent in a truthful manner historic events or certain personalities" and that "artistic or historic value [may] . . compensate in a certain measure for the boldness of such or such a scene."84 Again, however, the Tribunal will not be overly tolerant in this respect. The fact that the film ends in a socially desirable manner will not suffice in itself to save it from censorship. ${ }^{85}$

In the "White Slavery" case, the appellant argued that his film served a very good purpose by warning young girls of the evils of prostitution and putting them on guard against unscrupulous pimps. ${ }^{86}$ Many of the scenes were indeed coarse and brutal, he admitted, but this promoted his worthy end all the more by exposing evil in all its stark and ugly realism. ${ }^{87}$ The Tribunal's answer to these contentions is quite interesting. The court observed that Swiss

\footnotetext{
${ }^{82}$ Rey contre Ministre public, Tribunal Fédéral, May 10, 1963, 89 (1V.) Arrêts du Tribunal Fédéral 134 (Swit.).

${ }^{83}$ Sphinx-Film S. A. contre Conseil d'Etat, Tribunal Fédéral, Jan. 6, 1961, at 10 (Swit.); see text accompanying note 79 supra.

8؛ Sphinx-Film S. A. contre Conseil d'Etat, Tribunal Fédéral, Jan. 6, 1961, at 12 (Swit.).

${ }^{85}$ Id. at 10; Gamma-Film Distribution S. A. contre Conseil d'Etat, Tribunal Fédéral, March 3, 1954, at 8 (Swit.).

${ }^{80} I d$. at $2-3,5$.

${ }^{87}$ Id. at 2,5 .
} 
girls really didn't need this kind of protection since white slavery was not a problem of any proportions in the country. ${ }^{88}$ This would seem to indicate that the Swiss will consider "redeeming social value" in mitigation of a film's offensiveness only if that "value" has utility in the sense of possessing a causal connection to an existing problem in Swiss society.

Such an interpretation of "redeeming social value" has not received articulation by any Supreme Court Justice. The "utility" aspect of "value" is perhaps subsumed in the opinions of Justices Clark ${ }^{89}$ and White ${ }^{90}$ in the "Fanny Hill" case. On the other hand, it can be argued that "value" is inherently present in art or literature as an abstract proposition, but to attribute such a view to Justices Clark and White is somewhat speculative. The most logical explanation thus seems to be that the "utility" element of "redeeming social value" has simply been overlooked by the Supreme Court.

\section{Contemporary Community Standards}

The obscenity test currently applied by the United States Supreme Court requires that material be judged according to "contemporary community standards," ${ }^{11}$ but the meaning of this phrase has not been agreed upon by a majority of the Court in any case..$^{92}$

The phrase "contemporary community standards" is given a literal meaning by the Tribunal. The applicable standards are clearly "contemporary"-the test is the prevailing moral views of the community; ${ }^{33}$ and the Tribunal repeatedly asserts emphatically that the "community" is a local one:

[C]ircumstances ... differ from one canton to another. ${ }^{94}$

[T] he demands of order and public morality vary freely according to circumstances and local opinions; federal law would not be able to trace uniform limits between that which is permissible

${ }^{88}$ Id. at 9 .

${ }^{80}$ A Book Named "John Cleland's Memoirs of a Woman of Pleasure" v. Attorney Gen., 383 U.S. 413, 441 (1966) (Clark, J., dissenting).

${ }^{\circ 0} \mathrm{Id}$. at 460 (White, J., dissenting).

${ }^{21}$ See, e.g., Jacobellis v. Ohio, 378. U.S. 184, 191 (1964) (opinion of Brennan, J.).

${ }^{03}$ See Comment, 1965 Duke L.J. 596-601.

${ }^{03}$ See, e.g., Kunz contre Conseil d'Etat, Tribunal Fédéral, Dec. 7, 1960, at 2-3 (Swit.).

${ }^{94}$ Kunz contre Conseil d'Etat, Tribunal Fédéral, May 1, 1963, 89 (I.) Arrêts du Tribunal Fédéral 166, 169 (Swit.). 
and that which is not; it matters little, in this respect, what is the regulation laid down outside of such or such a canton. ${ }^{95}$

[O]pinions as to what constitutes a menace for public order and in particular for morals, and views as to means for their protection, depend for the most part upon given local data and upon the dominant political and religious ideas, [facts] which stand in opposition to the setting up of broad and uniform standards for the whole of Switzerland.96

\section{E. Comparisons to Other Similar Movies}

The New York Court of Appeals held in 1964 that if a book is no more offensive than other books which have been adjudicated unobscene by the Supreme Court, then the book under consideration cannot be obscene. ${ }^{97}$ A New Jersey court has rejected this "analogy" approach. ${ }^{88}$

Article 4 of the Swiss constitution includes an equal protection provision quite similar to the one appearing in the fourteenth amendment. The Tribunal Federal in the "Vacations for Naturists" case squarely grounded its reversal of the ban on this movie upon the equal protection provision.

[T]he Conseil d'Etat cannot forbid the film "Vacances Naturistes" without violating Article 4 of the Constitution. Indeed, hardly three months before, it had authorized the showing of the film "Nous irons à l'ile du Levant." Now in the actual versions of these two cinematographic strips there are no differences of fact permitting the authorizing of one and the banning of the other. ${ }^{90}$

The "analogy" approach thus assumes constitutional status in Switzerland. It should be carefully noted, however, that this equal protection argument can be made only if unequal treatment has been accorded the individual by the same canton: "[A complaint based on article 4] cannot be formulated successfully, according to firm court precedent, except by a person who has been legally treated in an unequal fashion by the same cantonal authority."100

${ }^{96}$ Sphinx-Film S. A. contre Conseil d'Etat, Tribunal Fédéral, Jan. 6, 1961, at 8 (Swit.).

${ }^{30}$ Filmklub Lucerne contre Conseil d'Etat, Tribunal Fédéral, July 12, 1961, 87 (I.) Arrêts du Tribunal Fédéral 117, 119 (1962) (Swit.).

${ }^{97}$ Larkin v. G. P. Putnam's Sons, 14 N.Y.2d 304, 252 N.Y.S.2d 7l, 200 N.E.2d 760 (1964).

${ }^{98}$ G. P. Putnam's Sons v. Callisi, 86 N.J. Super. 82, 205 A.2d 913 (Ch. 1964).

${ }^{99}$ Kunz contre Conseil d'Etat, Tribunal Fédéral, Dec. 7, 1960, at 9 (Swit.).

${ }^{100}$ Gamma-Film Distribution S. A. contre Conseil d'Etat, Tribunal Fedéral, March 3, 1954, at 10 (Swit.). 
In addition, a canton need not consistently maintain the same policy toward censorship. The censoring body is not eternally bound by its previous decisions; ${ }^{101}$ it is permitted to adopt a stricter standard. But before doing so, "it would have nonetheless to show some new circumstances which justify maintaining a more restrictive practice." If it fails to do so, then it is arbitrary and hence invalid to ban a movie similar to one previously sanctioned. ${ }^{102}$

A change in censorship policy was clearly shown in the case involving the movie "The Nudist Story." Geneva's Council of State had expressly stated it was convinced that exhibitions of prior movies indicated stricter controls over films were necessary. Since the Council firmly believed that exhibition of these prior movies had in fact produced a deleterious effect on morals, the change in attitude, said the Tribunal, was justified. ${ }^{103}$

In the "White Slavery" case, however, the change in administrative policy was not so express. In upholding the ban on this film, the Tribunal noted that the Zurich authorities were apparently adopting a more severe policy of control in view of certain "odious crimes" committed in Zurich toward the end of 1951.104 The Tribunal further stated:

Even if one wanted to admit that the Conseil d'Etat had not introduced or consciously confirmed a more severe censorship policy, it would not follow from this that appellant is able to plead unequal treatment. It is natural that the evaluation of films should be adapted to the circumstances of life and should be modified during the course of the years. And if, in the concrete case, the authority in effect applies criteria more rigorous than previously, one cannot demand, in view of equality of treatment, that it should alter its views about former decisions, especially since, as is the case for the Canton of Zurich, the number of films to be examined each year is very large. ${ }^{105}$

The ease with which the Tribunal will thus apparently "find" a change in censorship policy diminishes the probability of a successful argument based on the equal protection provision. The probability of success will also depend, of course, on the amount of

\footnotetext{
${ }^{102}$ Kunz contre Conseil d'Etat, Tribunal Fédéral, Dec. 7, 1960, at 9 (Swit.).

${ }^{103} \mathrm{Id}$. at 10.

${ }^{103}$ Regina-Film S. A. contre Conseil d'Etat, Tribunal Fédéral, Sept. 25, 1963, at 2-3,

9 (Swit.).

10؛ Kunz contre Conseil d'Etat, Tribunal Fédéral, Dec. 7, 1960, at 11 (Swit.).

${ }^{105}$ Ibid.
} 
deference the Tribunal will pay to the censoring body's decision. That great deference will be given is indicated by the following statement of the Tribunal in the "Bright Sun" case: "It can seriously be doubted that the constitutional principle of equality of treatment is often applicable in the question of the cinema: there are hardly two films entirely the same." 106

While the scope of protection available to the exhibitor by virtue of a "similar films" argument based on the equal protection provision thus seems to be rather narrow, the fact remains that such a concept does exist.' There is no immediately apparent reason why such a concept does not likewise exist under the fourteenth amendment's equal protection clause. It is true that a factual comparison of two movies or two books to determine which is "worse" presents difficult problems of proof. Nevertheless, it seems entirely possible for an exhibitor in the United States who believes that his film is no more offensive than one already sanctioned by the censoring authority to base a forceful argument on the equal protection clause. Indeed, such an argument would afford an exhibitor the only avenue of relief if both his film. and the one already sanctioned were in fact obscene under the constitutional standards developed by the Supreme Court. ${ }^{107}$

\section{F. The Movie's Effect on the Audience}

The definitional approach adopted toward obscenity by the Supreme Court dictates that a determination first be made as to whether the item in issue is "obscene." If it is, then no first amendment protection is afforded it. According to the plurality opinion in the most recent Supreme Court case, one element of the obscenity definition is whether "the material is utterly without redeeming social value." $10 \mathrm{~s}$ On the other hand, three of the Justices deny that this consideration is part of the constitutional test. ${ }^{100}$ Among them

\footnotetext{
${ }^{100}$ Sphinx-Film S. A. contre Conseil d'Etat, Tribunal Fédéral, Jan. 6, 1961, at 11 (Swit.).

${ }^{107}$ Of course, the possibility that the censoring authority under such an attack might reverse its sanction of the prior movie should not be overlooked. But compare Gamma-Film Distribution S. A. contre Conseil d'Etat, Tribunal Fédéral, March 8, 1954, at 11 (Swit.): "[I]f . . the authority in effect applies criteria more rigorous than previously, one cannot demand, in view of equality of treatment, that it should alter its views about former decisions ...."

${ }^{108}$ A Book Named "John Cleland's Memoirs of a Woman of Pleasure" v. Attorncy Gen., 383 U.S. 413, 418 (1966) (opinion of Brennan, J.).

${ }^{100}$ See id. at $441-45$ (Clark, J., dissenting); id. at 458.59 (Haxlan, J., dissenting); id. at 460-62 (White, J., dissenting).
} 
is Justice Clark, who argues that even if the "redeeming social value" test is part of the obscenity definition, then the inquiry concerning this element must not merely consider "artistic, literary, and historical qualities," but must also "balance alleged esthetic merit against the harmful consequences that may flow from pornography." 110

If the possibility that salacious material may produce harmful effects on the audience is found to be a relevant consideration, there are two methods by which this factor might be injected into the constitutional structure. It could be subsumed into the obscenity definition itself, thus further befouling an already befouled problem. Or it could be considered separately: once the material has been found to be unobscene, the effect on the audience would be one factor to be considered in an ordinary first amendment analysis. If a balancing approach were utilized, the restriction on speech would be weighed against the gravity and probability of the supposed harmful effects.

The Swiss have faced the problem of effect on the audience, and their basic position seems to be in agreement with Justice Clark. Thus, when an appellant pointed out that the critic's reviews of his film had been "laudatory," the Tribunal noted that "this, insofar as it appraises the quality of the work, looks only at the technical and artistic aspect; now it is not this which is decisive in the viewpoint of the police administration . ...."111

Indeed, the effect on the audience is perhaps the most important factor considered by the Swiss in their censorship approach:

That which ought to determine the attitude of the public authority is the probable subjective reaction of the ordinary public in the cinema hall. It varies according to many factors, among which, the age of the viewer and the times and locale of the presentation appear to be the most important. Thus it is that in a period of a recrudence of crime (or of certain crimes) the public authority will show itself more demanding in respect to such a category of films. ${ }^{112}$

${ }^{110} \mathrm{Id}$. at 451 (Clark, J., dissenting).

${ }^{111}$ Sphinx-Film S. A. contre Conseil d'Etat, Tribunal Fédéral, Jan. 6, 1961, at 10 (Swit.).

${ }^{112}$ Id. at 6; see note 13 supra.

It is not the details of a magazine but rather the total impression on the reader which is decisive in adjudging obscenity. Rey contre Ministre public, Tribunal Fédéral, Dec. 3, 1963, [1964] Journal des Tribunaux 149 (Swit.). 
Censorship authorities are allowed to adjust their standards of control over the films submitted to them according to the circumstances of the times. When certain "odious crimes" were committed in Zurich, for example, a stricter policy of censorship was justified.113

All of this raises the interesting question of what factual burden of proof should be placed on the censoring authority to show that its action is reasonably calculated to meet some recognizable public interest and that some rational connection exists between the censorship policy and the furthering of that public interest. Authority in this country certainly has given no uniform answer to whether there is any relationship between pornography and antisocial conduct. ${ }^{114}$ A concomitant problem is what effect legislative or quasi-legislative findings should have on judicial inquiry into the factual underpinnings of such findings. The Swiss have obviously decided these questions in favor of deference to local judgments; it is uncertain whether this policy would be followed in the United States.

A more specific problem also arises in the area of the effect of salacious material on the audience. The holding in Ginzburg $v$. United States, ${ }^{115}$ as well as dicta from that and other cases, indicates that the identity of the audience toward which the material is directed bears on whether censorship will be allowed. Thus it is not impossible that the Court may decide that a certain item can be constitutionally banned from a showing or distribution only to certain groups, or that what is "obscenity" in some circumstances may not be "obscenity" under others. Such a holding would be in accord with statements by the Swiss Tribunal. For example, the Tribunal has indicated that the permissible limits of regulation for a movie are different than for a night club.116 Likewise, the Tribunal has raised a possible distinction based on the age of the audience:

One might wonder ... if, insofar as the Conseil d'Etat [in this case] intends to protect youth only, it should not, in order to

113 Gamma-Film Distribution S. A. contre Conseil d'Etat, Tribunal Fédéral, March 3, 1954, at 11 (Swit.).

114 For an indication of the effect of this disagreement on the Supreme Court, com. pare A Book Named "John Cleland's Memoirs of a Woman of Pleasure" v. Attorney Gen., 383 U.S. 413, 432-33 \& n.11 (1966) (Douglas, J., concurring), with id. at 451.53 (Clark, J., dissenting). (1957).

115383 U.S. 463 (1966). See also in this connection Butler v. Michigan, 852 U.S. 880

116. Regina-Film S. A. contre Conseil d'Etat, Tribunal Fédéral, Sept. 25, 1963, at 3 (Swit.). 
be consistent with the principle of proper proportion, limit itself to the banning of the film for persons who have not reached a certain age. ${ }^{117}$

It was not necessary to answer this question in the instant case, because the appellant had not raised the issue. ${ }^{118}$ But it is not at all clear that the appellant would have been successful even if it had. The censoring authority in the case had specifically grounded its ban on the danger the film posed for youth. ${ }^{119}$ Nevertheless, the Tribunal blithely continued:

However, it is the possibility given the general public of freely seeing nudists that the Conseil d'Etat is against. But nudists appear on the screen from beginning to end of this litigious film. Thus the entire film can indeed be forbidden. ${ }^{120}$

Perhaps the Tribunal has shifted its ground for affirmance; but if it has not, it seems to be applying a tight series of syllogisms: Young people need protection against corrupting influences. Adults who see nudist films could become a corrupting influence. Ergo, nudist films should not be shown to adults.

This reasoning is not wholly without merit, however. Given the goal of protection of youth, the inquiry in the United States, at least, would be whether this means of effectuating that goal is sufficiently rational to allow suppression of the movie-whether subsumed under the "obscenity" definition or via an ordinary first amendment inquiry.

\section{IV}

\section{Other Aspects of Swiss Censorship Law}

Several other elements of Swiss censorship law have no directly analogous counterpart in American law, but are nevertheless relevant to a comparative study. These will be discussed below.

${ }^{117}$ Id. at 7 ; see note 82 supra and accompanying text.

In Sutz contre Zurich, Tribunal Fédéral, May 13, 1925, 51 (I.) Arrêts du Tri-. bunal Fédéral 37 (Swit.), the Tribunal sustained cantonal laws forbidding the showing of films to certain age groups. Nearly every canton classifies each film into age requirements of over eighteen, over sixteen, over twelve, or over seven years of age. Admission must be denied to those who do not qualify.

${ }^{118}$ Regina-Film S. A. contre Conseil d'Etat, Tribunal Fédéral, Sept. 25, 1963, at

7 (Swit.).

110 See id. at 9 .

${ }^{120}$ Id. at 7 . 


\section{A. Advertising}

The method of advertising and distributing the material, the Supreme Court has said, "is relevant to the application of the Roth test."12I If the material is being "pandered," it is more likely to be "obscene."122 This issue has arisen in a related context in Swiss law, and the following paragraphs show the extent of cantonal control which has been deemed permissible.

Fribourg, a canton just north of Geneva and Vaud, is known for censorship laws somewhat more restrictive than those in many of the other states in the Swiss Confederation. The film "Nous irons à l'ile du Levant" was banned in 1960 by its control board, ${ }^{128}$ permitted in the cantons which fianked its border. But Werner Kunz, the enterprising promoter of naturist spectacles, decided that if the nudists could not go to Fribourg, Fribourg would be made to go to the nudists. ${ }^{124} \mathrm{He}$ accordingly arranged to show the banned film in Payerne, a small town lying just south inside the boundaries of the canton of Vaud, where the movie had been authorized. Three days before opening night, he had advertisements stating "we will go" deposited in letter boxes in Fribourg's capital city. The handbills gave the hours of the showings as well as the hours of trains leaving for Payerne. And, of course, Kunz made the forbidden fruit all the more appetizing by underscoring the fact that the film was banned in Fribourg.

Fribourg retaliated to the challenge by fining Kunz 400 francs (\$92). The legal basis for such punishment was a law forbidding films contrary to public order and good morals, plus an ordinance prohibiting all advertisements of the same character. ${ }^{125}$

\footnotetext{
${ }^{191}$ Ginzburg v. United States, 383 U.S. 463, 471 (1966).
}

The Swiss high court has ruled that the cantons may ban all cinema advertising near schools. Gcorgopoulos contre Bâle-Ville, Tribunal Fédéral, Oct. 28, 1927, 53 (I.) Arrêts du Tribunal Fédéral 265 (Swit.). But it has said that prior censorship of film ads placed an unreasonable burden on the cinema industry. Ciné-Spectacles S. A. contre Genève, Tribunal Fédéral, Oct. 22, 1952, 78 (I.) Arrêts du Tribunal Fédéral 278 - (Swit.). The court noted that cantons could achieve the same end by prosecuting offenders for printing immoral or obscene material. The judges observed that this ruling was not inconsistent with its allowance of compulsory prior review of the films tbemselves. See note 66 supra and accompanying text; note 139 infra.

${ }^{122}$ Ginzburg v. United States, 383 U.S. 463, 465-66, 470-71 (1966).

${ }^{123}$ See Kunz contre Conseil d'Etat, Tribunal Fédéral, Sept. 20, 1961, [1962] Journal des Tribunaux 340 (Swit.).

124 Ibid.

${ }^{125}$ Ibid. 
In his appeal before the Tribunal Federal, Kunz argued that the punishment meted out to him was an unconstitutional restraint of trade and commerce, guaranteed by article 31 of the constitution, and that it violated the equal protection clause of article $4 .{ }^{126}$

The Tribunal carefully detailed the extent of protection afforded by these guarantees. It noted that commerce could be regulated for the common good only insofar as necessary and that the cantons could not pass discriminatory laws against businesses located beyond its own borders. ${ }^{127}$

The judges also observed that a canton could not forbid its citizens the right to travel beyond its frontiers, even to preserve them from physical or moral evil. ${ }^{28}$ This raises an interesting point: Kunz had not urged the people of Fribourg to do anything illegal, and there is no suggestion in the Tribunal's opinion that the handbill was in any way salacious or improper. In effect, Kunz merely urged people to exercise a constitutional right in Fribourg-travel to a neighboring canton-and to perform another perfectly legal act in the canton of Vaud-view a film authorized by law in that canton. Moreover, as the Tribunal pointed out, its previous decisions had recognized that "in general ... the interests of a canton are suffciently protected" against possible abuses of an enterprise when that enterprise has been authorized in its home canton. ${ }^{129}$

All this being said, the Tribunal proceeded to uphold Fribourg's right to punish Kunz by fine. This conclusion followed once the Tribunal had set forth its major premise: the general task of cinema censorship is to keep the public from seeing films deemed dangerous. ${ }^{130}$ In brief, the rationale was "let the end be legitimate... and all means which are appropriate ... are constitutional."131 In putting flesh on this skeleton, the Tribunal made the following pertinent observations:

The chore of the movie censor of the cantons is to protect public order and good morals. To this end, the censor strives to keep from the public films which, by reason of the scenes produced or of the manner in which they are presented, are apt to disturb

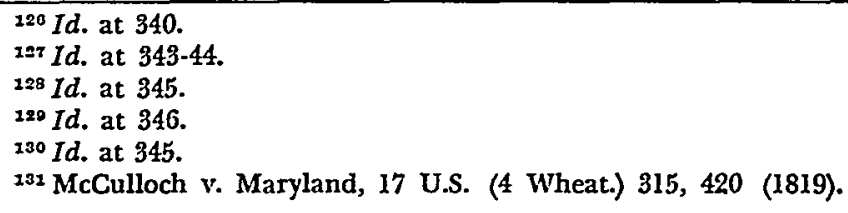


the internal or external peace of individuals, to offend their moral or religious sentiments, to exercise an evil effect or to excite to crime. ${ }^{132}$

As to Kunz's handbill, the Tribunal continued:

Consequently to oppose this kind of advertisement constitutes an appropriate means for attaining the end which the censor has proposed to himself. If the canton were not able to act against this ad, the efficacy of its control would be seriously compromised by the easy means of communication existing amongst the different cantonal States. Once cantonal authorities have arrived at the conclusion that a film puts public order and good morals in danger . . . they ought therefore to be able to take care that this danger does not reach, from outside [its boundaries] an important portion of the population..$^{133}$

The Tribunal referred to a 1944 decision upholding a law of a canton which forbade newspaper advertisements for unlicensed doctors. ${ }^{134}$ In this case, the Tribunal Federal had justified the law as a legitimate defense of its own citizens-and of its own doctorsagainst those cantons which did not have high medical standards; otherwise the standard in all of the cantons might be reduced to the lowest common denominator. ${ }^{135}$

The Tribunal admitted that generally speaking the laws of one canton would afford sufficient protection for all people, but it added an important qualification:

However, it [the Tribunal] makes an exception for the hypothesis where police prescriptions of the different cantons impose different regulations for the same public performance. This is the case for the censor. ${ }^{136}$

What follows is highly significant:

The question of knowing when public order and particularly good morals are put in danger and how it is fitting to protect these legal goods (ces biens juridiques), depends in a large measure on local conditions and on the dominant opinions within the

\footnotetext{
${ }^{132}$ Kunz contre Conseil d'Etat, Tribunal Fédéral, Sept. 20, 1961, [1962] Journal des Tribunaux 340, 345. (Swit.).

133 Ibid.

134 Ibid.

${ }_{135}$ Ulrich contre Conseil d'Etat, Tribunal Fédéral, April 3, 1944, 70 (I.) Arrêts du Tribunal Fédéral 71 (Swit.).

${ }^{138}$ Kunz contre Conseil d'Etat, Tribunal Fédéral, Sept. 20, 1961, [1962] Journal des Tribunaux 340, 346 (Swit.).
} 
political and religious domain, in such a way that the decision of one canton is not necessarily valid for another canton. ${ }^{137}$

But if a canton is permitted to forbid Kunz's handbills, should they not also be permitted to exclude from their borders newspapers from other cantons carrying the same message by way of an advertisement? The Tribunal was aware of the possibility, but refused to be frightened by "the parade of the horribles." It merely observed, in passing, that "it wasn't the place here for examining how the diffculty would be solved."138 In typical Swiss fashion, the judges indicated that they would cross that bridge when they reached it. It seems safe to say that they would judge this to be an "unreasonable" restraint of trade and of the press; the regulation under consideration now, on the other hand, simply seemed "reasonable."

\section{B. Alternative Means}

One factor bearing on constitutional issues in the United States which has assumed increasing importance recently is the availability of alternative means to accomplish some legitimate social goalalternative means which do not tread so heavily on individual rights as the mean chosen. The Swiss Tribunal has at times suggested that the cantons consider alternative means, but has not to date proposed. the concept as a constitutional limitation. ${ }^{139}$

The Tribunal has, however, raised the "alternative means" idea in a reverse form: as a limitation on the individual. In the "White Slavery" case, the appellant argued that his film, though admittedly coarse and brutal, nevertheless conveyed an important social message. $^{140}$ In refuting this contention, the Tribunal pointed out that the same social message could have been conveyed with a much less shocking exhibition. ${ }^{141}$ Thus the alternative means idea was ap-

\footnotetext{
${ }^{137}$ Ibid.

138 Ibid.

${ }^{130}$ See, e.g., Regina-Film S. A. contre Conseil d'Etat, Tribunal Fédéral, Sept. 25, 1963, at 7 (Swit.); Gamma-Film Distribution S. A. contre Conseil d'Etat, Tribunal Fédéral, March 3, 1954, at 11 (Swit.). See also Ciné-Spectacles S. A. contre Genève, Tribunal Fédéral, Oct. 22, 1952, 78 (I.) Arrêts du Tribunal Fédéral 278 (Swit.), where the court, in disallowing prior censorship of advertisements, suggested post-prosecution as an alternative. The judges noted that it is easy for film promoters to judge for themselves whether a proposed ad will be immoral, but that it often requires a board of experts to make a sound moral judgment of a film. Thus, previous review was reasonable in the one case and not in the other.

${ }^{100}$ Gamma-Film Distribution S. A. contre Conseil d'Etat, Tribunal Fédéral, March 3, 1954, at 2-3, 5 (Swit.).

111 Id. at 9.
} 
plied to the appellant as a factor in determining the propriety of his film. ${ }^{142}$

\section{Censorship Outside the Obscenity Area}

The obscenity aspect of censorship in the United States looms so large that other grounds for banning movies are often obscured. It is often forgotten that the first case in which the Supreme Court extended first amendment protection to movies-Joseph Burstyn, Inc. v. Wilson 143 -involved a film that was allegedly "sacrilegious," not "obscene." Nevertheless, most of the cases which have reached the Supreme Court have arisen under the obscenity aegis, and no case involving censorship on other grounds has been decided except in a prior restraint context. The fact that censors in this country do ban movies on other than obscenity grounds can hardly be doubted. ${ }^{144}$ That a case involving such a prohibition will reach the Supreme Court thus seems possible, and the approach that the Court will use-whether definitional, balancing, or something else--is subject to speculation. ${ }^{145}$

The Swiss censorship authorities quite regularly prohibit the showing of films on other than obscenity grounds-such as glorification of crime. In an interview in 1965 with the head of one of the cantonal movie boards, this writer elicited the following statement: "Westerns always get a green light, for crime is always punished, virtue always triumphs."

This pedestrian canon is basically the one utilized by the Tribunal Federal in its review of such cases. If the film actually suggests

1.2 Compare A Book Named "John Cleland's Memoirs of a Woman of Pleasure" v. Attorney Gen., 383 U.S. 413,462 (1966) (White, J., dissenting): "[Roth does not mean] - . that if books like Fanny Hill are unprotected, their nonprurient appeal is necessarily lost to the world. Literary style, bistory, teachings about sex, character description (even of a prostitute) or moral lessons need not come wrapped in such packages."

143 343 U.S. 495 (1952).

14t For a long list of examples of censors' excisions in a variety of contexts, see Times Film Corp. v. City of Chicago, 365 U.S. 43, 69-73 (1961) (Warren, C.J., dis. senting).

${ }^{116}$ The Court could apply the same definitional approach as is used with obscenity. Thus, if something were "sacrilegious" or "criminal," it would not be "speech," and thus not receive first amendment protection. The task of constitutionally defining "sacrilegious" or "criminal" would probably produce the same difficulties encountered in defining "obscenity."

These difficulties might lead the Court to use a balancing approach. The interest of society in retarding antisocial conduct would be weighed against the benefits of free dissemination of ideas. 
"that the perfect crime is possible and that it pays off handsomely," that is a sufficient ground for prohibiting it.

In other nonobscenity situations, the Tribunal will apply the same criteria that are utilized in judging allegedly obscene films.

\section{Freedom of the Press}

Article 55 of the federal constitution of Switzerland states that "the freedom of the press is guaranteed." ${ }^{147}$ One might well ask why the aggrieved movie promoters did not advance the argument that this basic liberty was infringed by the respective censorship laws. In only one of the cases which the author has studied was there even a modest suggestion that this might provide a salient point from which to attack the imposed ban. ${ }^{148}$ The answer to such a query is simply that in Switzerland movies are not considered to come within the definition of the press. The following makes this abundantly clear.

On October 19, 1951, when there was talk of amending article 55 of the federal constitution, the Conseil Féderal-the Swiss collegiate executive of seven members-stated:

The guarantee of the liberty of the press is applicable to products of a printing establishment and to materials of information and to manuscripts destined to be published among those products of the printing establishment; the guarantee of the liberty of the press is not applicable, on the other hand, to the cinema and the radio. ${ }^{149}$

In 1956 there was much discussion about the amendment contemplated for article 27 of the constitution. On February 24 of that year, the Conseil Fédéral addressed the following message to the Federal Assembly-the bicameral legislature of the Republic:

Since the cinema does not come by definition within the notion of the press, neither is liberty of the press, guaranteed by the Constitution, extended to the cinema. We have already stated this in

\footnotetext{
${ }^{140}$ Sphinx-Film S. A. contre Conseil d'Etat, Tribunal Fédéral, Jan. 6, 1961, at 10 (Swit.).

${ }^{247}$ There is no separate "freedom of speech" guarantee, but it is understood to be embraced by the "freedom of the press" clause. Filmklub Lucerne contre Conseil d'Etat, Tribunal Fédéral, July 12, 1961, 87 (I.) Arrêts du Tribunal Fédéral 117 (1962) (Swit.). See note 9 supra.

${ }^{148}$ Gamma-Film Distribution S. A. contre Conseil d'Etat, Tribunal Fédéral, March 3, 1954, at 9-10 (Swit.).

240 [1951] III Feuille Fédérale 261.
} 
our message of October 19, 1951, concerning the revision of Article 55 of the Constitution. 150

The Tribunal Federal had an occasion to express itself on the matter on July 12, 1961, in the case of Filmklub Lucerne contre Conseil d'Etat: ${ }^{151}$

[T] he appellant arms himself with Article 55 which guarantees liberty of the press and thereby in a general manner every manifestation of opinion. In its decrees, still unpublished, rendered June 14, 1918, in the case of Burckhardt contre Lucerne and on January 30, 1931 in the case of Praesens-Film AG contre Shaffhouse, the Tribunal Federal said, on conclusive grounds, that a film is not a product of the press and that its showing, just as a theatrical performance, does not enjoy the liberty assured to the press. ${ }^{152}$

Approaching the case at hand, the Tribunal continued:

There is no reason for departing from this case law, which takes on particular importance for prior censorship; and such an interpretation accords with the general opinion of commentators of the Constitution. ${ }^{153}$

\section{E. Censorship of Private Showings}

The Lucerne Film Club is a private association whose members allegedly are seriously interested in the aesthetic values of certain movies. Article 56 of the federal constitution provides that "citizens have the righit to form associations, provided that the objects and methods of such associations are not unlawful or dangerous to the State." The possibility that private associations could be utilized to evade the censorship laws may have underlain the Tribunal's rejection of the Film Club's contention that article 56 thus protected its showing of questionable films: " $[\mathrm{P}]$ rior censorship of performances in a cine-club is reconcilable with liberty of association."154

\section{F. Freedom of Commerce}

Article 31 of Switzerland's federal constitution reads in part: "The freedom of trade and commerce is guaranteed throughout the

\footnotetext{
${ }^{150}$ [1956] I Feuille Fédérale 479.

'x1 Tribunal Fédéral, July 12, 1961, 87 (L.) Arrêts du Tribunal Fédéral 117 (1962) (Swit.).

". 158 Ibid.

${ }^{253}$ Ibid.

25 Ibid.
} 
Confederation ...." This article has been called a "free competition and free trade" guarantee, in the sense that those words are understood by classical economists. ${ }^{155}$ It is also relevant to point out that in Swiss law there is no artificial distinction between interstate and intrastate commerce. Therefore, that a certain business is purely local does not in itself justify cantonal infringement of this freedom.

When appellants have raised this provision as a retardant to movie censorship, the Tribunal has conceded that the film industry is entitled to its protection just as is any industry. But since movies "are able to involve great dangers for the public welfare, considerable restrictions ... are admissible." 156 Additionally, the Tribunal has alluded to the second paragraph of article 31, which permits "cantonal regulations concerning the exercise of commercial and industrial occupations ...." Nevertheless, the Tribunal recognizes that commerce can be regulated for the common good only insofar as necessary, and unreasonable regnlation will not be allowed. ${ }^{157}$

\section{$\mathrm{V}$}

\section{Conclusion}

In an area where uncertainty abounds, an examination of the solutions found by another system of law is most instructive. Besides providing a fresh approach and varying insights to the problem, a comparative analysis promotes reevaluation of basic policy considerations.

Much can be learned by comparing the Swiss and American approaches to specific aspects of the censorship dilemma. The foregoing pages bring the issues into sharper focus and suggest different and novel methods for surveying these specific problems.

But this is not the only purpose of this article. Rather, it is hoped that the reader can bring a more reasoned viewpoint to the over-all problem of censorship after perusing the material above. It is not suggested that the Swiss attitude be unquestionably adopted into American thinking; certainly there are enough significant differences between the situations in the two countries to caution against any such a proposal. But the Swiss approach should be con-

158 Hughes, The Federal Constrtution of Switzerland 31 (1954).

${ }^{156}$ Gamma-Film Distribution S. A. contre Conseil d'Etat, Tribunal Fédéral, March 3, 1954, at 7 (Swit.).

${ }^{157}$ E.g., Kunz contre Conseil d'Etat, Tribunal Fédéral, Sept. 20, 1961, [1962] Journal des Tribunaux 340, 343-44 (Swit.). 
sidered as one alternative. If nothing else, it has the virtue of working well.

This general Swiss attitude is quite clear. The Tribunal Federal exercises the maximum of restraint in judging acts by the cantons to censure the movies. Its view is that local conditions and community standards ought to determine what laws, if any, be enacted, and that cantonal authorities are best placed to judge these factors. It feels that any attempt to impose uniform laws throughout the Republic would be unwise. ${ }^{158}$ If the multitude of cinema regulations in the tiny Republic of Switzerland sometimes causes inconvenience, most Swiss seem to accept it as the price they must pay for keeping their federal system of government alive and functioning.

${ }^{188}$ In October 1965, for example, "The Nudist Story" was playing openly in Bern, the capital of the Republic of Switzerland. Perhaps this demonstrates how strong, how deep, how varied, how colorful, and how robust is the spirit of Swiss federalism. 